\title{
Studi Sejarah Letusan Samalas Berdasarkan Stratigrafi Endapan Vulkanik di Daerah Gangga, Lombok Utara
}

\author{
Muhammad Zuhdi ${ }^{1}$, Syamsuddin $^{2}$, Bakti Sukrisna ${ }^{2}$, Syahrial Ayub ${ }^{1}$, Muhammad Taufik ${ }^{1}$ \\ ${ }^{1}$ Program Studi Pendidikan Fisika, FKIP, Universitas Mataram, Lombok, Indonesia \\ ${ }^{2}$ Program Studi Fisika, FMIPA, Universitas Mataram, Lombok, Indonesia
}

\author{
Article history \\ *Corresponding Author: \\ Muhammad Zuhdi, Program \\ Studi Pendidikan Fisika, FKIP, \\ Universitas Mataram, Lombok, \\ Indonesia. \\ Email: mzuhdi@unram.ac.id
}

\begin{abstract}
Gunung Samalas yang kini disebut dengan Gunung Rinjani adalah gunung api dengan letusan terbesar sepanjang sejarah ummat manusia dari zaman Nabi Ibrahim hingga kini. Penemuan ini didasarkan pada cerita sejarah bencana kelaparan yang melanda hampir separuh belahan dunia dari sekitar Pasifik hingga ujung barat benua Eropa. Letusan gunung besar gunung samalas sebelumnya terjadi sekitar 2500 tahun yang lalu. Penelitian ini bertujuan untuk mengungkap letusan besar yang pernah terjadi di Gunung Samalas berdasarkan stratigrafi endapan vulkanik di daerah Gangga, Lombok Utara. Hasil penelitian menunjukkan bahwa terdapat letusan besar yang terjadi sebelum 2500 tahun yang lalu, sehingga dapat disimpulkan bahwa terdapat 3 letusan besar yang telah terjadi pada Gunung Samalas. Penelitian awal ini masih memerlukan dukungan dari data dari tempat lain dan data hasil dating dari lapisan pumice yang diduga sebagai hasil letusan paling awal.
\end{abstract}

Keywords: Letusan Samalas; Endapan Vulkanik; Lombok.

\section{Pendahuluan}

Gunung Rinjani merupakan salah satu Gunung api tertinggi di Indonesia dengan ketinggian mencapai 3.726 meter di atas permukaan laut. Gunung Rinjani terletak di pulau Lombok dan merupakan satu-satunya gunung api aktif yang ada di pulau ini. RinjaniSamalas Volcanic Complex terletak pada Lesser Sunda Arc yang berada di ujung paling timur (Metrich, 2018).

Gunung Rinjani berada diantara 2 gunung api aktif lainnya yaitu gunung Agung yang ada di sebelah baratnya dan Gunung Tambora yang ada di sisi timurnya. Gunung Agung berada di Pulau Bali tepatnya di Kabupaten Karangasem, sedangkan Gunung Tambora berada di Pulau Sumbawa tepatnya di sebelah utara Kota Dompu dan Bima.

Secara geologi Gunung Rinjani kemungkinan terbentuk oleh adanya zona subduksi antara lempeng Indo-Australia yang menunjam di bawah lempeng Eurasia (Zuhdi, 2019). Tunjaman ini menciptakan rangkaian pegunungan yang terbentang dari Pulau Sumatera, Jawa, Bali, Nusa Tenggara Barat, hingga Nusa Tenggara Timur. Sistem pegunungan ini berupa pegununganpegunungan lipatan serta gunung-gunung api yang sebagian besar masih aktif. Diperkirakan sumber dari energi yang menyuplai energi panas gunung api aktif ini adalah gesekan antara lempeng Eurasia dan lempeng indo-australia pada zona subduksi. Lokasi Gunung Rinjani ini berada pada salah satu bagian dari ring of fire (Ludman, 1982).

Gunung api yang ada di Indonesia merupakan kumpulan gunung api teraktif di dunia dan beberapa diantaranya merupakan gunung dengan sejarah letusan yang sangat besar, yaitu gunung api Toba, Gunung Gamalas ,Gunung Krakatau dan Gunung Tambora.

Gunung api Toba terkenal dengan nama Toba Supervolcano. Nama ini didasarkan pada besarnya letusan yang sangat dahsyat yang terjadi di zaman prasejarah sehingga jumlah kurban jiwa maupun harta benda tidak tercatat dalam sejarah yang diperkirakan terjadi sekitar 
75000 tahun yang lalu. Letusan Gunung Toba diperkirakan merupakan letusan gunung api terbesar yang pernah terjadi di muka bumi.

Pada abad ke-13 hampir seluruh belahan dunia mengalami kegelapan total yang terjadi hampir 3 tahun yang menyebabkan bencana kelaparan di berbagai belahan dunia bencana ini tercatat dalam sejarah di berbagai negara. Bahkan dii Inggris telah terjadi krisis makanan sebagai akibat letusan Gunung Samalas ini (Campbell, 2017).

Penemuan aerosol vulkanik di Benua Antartika telah membawa kecurigaan adanya letusan sangat besar yang terjadi pada masa tertentu. Penemuan ini telah membawa para peneliti gunung api dunia untuk menyelidiki asal-muasal aerosol vulkanik yang ada di Antartika tersebut. Berbagai gunung api di belahan dunia telah diteliti kandungan mineral nya dan ternyata kandungan mineral aerosol di Antartika sangat cocok dengan kandungan aerosol yang terjadi di Gunung Rinjani yang dulu disebut dengan Gunung Samalas. Berbagai fakta sejarah menunjukkan bahwa letusan samalas ini telah membawa dampak iklim yang sangat besar di berbagai-bagai belahan dunia (Lavigne dkk, 2013).

Menurut penelitian terdahulu Gunung samalas telah mengalami dua kali letusan besar. Letusan pertama terjadi sekitar 2500 tahun yang lalu atau 500 tahun sebelum Masehi, sedangkan letusan kedua terjadi di di pertengahan abad ke13.

Jejak sejarah letusan gunung api dapat dilihat dengan baik melalui endapan vulkanik yang berada ada di sekitar area letusan gunung api tersebut. Di daerah Gangga, Kabupaten Lombok Utara, terdapat suatu tambang material pasir yang dilakukan dengan mengeruk lapisanlapisan pasir dari atas menuju ke bawah menggunakan alat berat. Dari singkapan lapisan pasir di sekitar tambang inilah dipelajari stratigrafi dan sejarah letusan Gunung Rinjani.

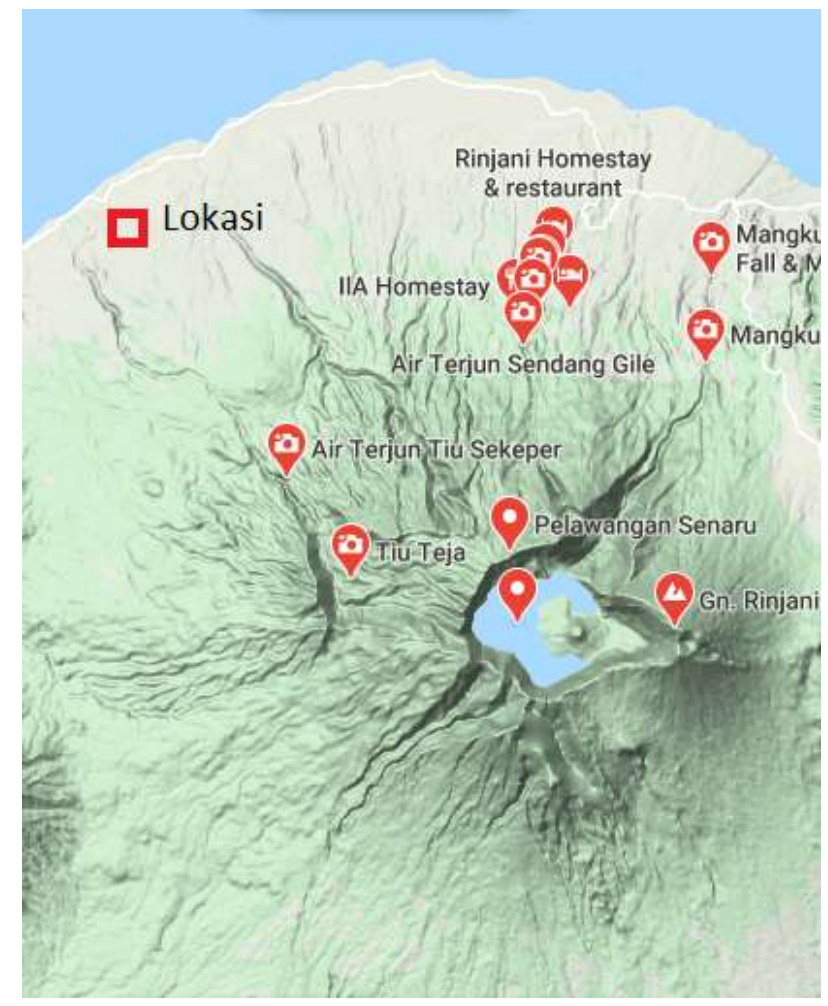

Gambar 1. Peta lokasi penelitian

Gambar 1 menunjukkan peta lokasi penelitian di daerah Gangga dengan disertai posisi relatif terhadap letak puncak Gunung Rinjani. Lokasi ini termasuk dalam zona rawan amplifikasi berdasarkan hasil penelitian menggunakan metode HVSR atau Horizontal to Vertical Seismic Ratio (Syamsuddin, dkk, 2018).

\section{Metode}

Letusan gunung api dengan skala besar selalu menghasilkan jenis batuan pumice yang juga dikenal dengan sebutan batu apung. Pumice memiliki ciri berwarna terang dan memiliki pori-pori besar yang terkunci dan tidak saling terhubung. Pori-pori inilah yang membuat batu apung menjadi sangat ringan karena di dalamnya terdapat gas yang terjebak dalam pori sehingga tidak dapat digantikan oleh material lain seperti air karena sifatnya yang tidak permeable.

Letusan besar selalu berhubungan dengan tekanan didalam jam kantong magma yang sangat besar akibat adanya tekanan gas yang timbul saat aktivitas vulkanik. Tekanan besar inilah yang yang menimbulkan letusan yang sangat besar, sehingga letusan besar selalu 
dicirikann adanya batu apung atau pumice. Letusan kecil dan sedang biasanya menghasilkan material piroklastik berbentuk batu dan pasir tetapi tidak menghasilkan pumice. Tumpukan material yang dihasilkan oleh letusan dan aktivitas gunung api terekam pada stratigrafi perlapisan di sekitar Gunung tersebut. Piroklastik yang terlempar ke udara di endapkan ke permukaan dengan waktu yang berbeda-beda tergantung ukurannya. (Billings, 1946).

Gangga merupakan daerah aliran sungai dimana material vulkanik diendapkan. Stratigrafi lapisan-lapisan endapan vulkanik di daerah Gangga dapat menggambarkan sejarah letusan Gunung Rinjani pada masa lampau.

Di daerah ini terdapat tiga jenis lapisan pumice yaitu, pumice yang berwarna putih yang diperkirakan hasil letusan abad ke-13, lapisan pumice berwarna pink yang diperkirakan merupakan hasil letusan tahun 500 sebelum Masehi dan lapisan pumice berwarna kuning yang merupakan lapisan pumice yang paling tua. Prinsip superposisi menyatakan bahwa batuan yang terendapkan pada tempat yang lebih dalam memiliki umur yang lebih tua daripada batuan di atasnya.

Pada kondisi pengendapan hasil erosi biasa, perlapisan setebal 1 meter dapat diinterpretasikan sebagai lapisan yang terjadi sebagai hasil endapan selama 1000 tahun. Lapisan setebal 3 meter dapat terjadi di dalam masa pengendapan 3000 tahun dan seterusnya. Pada endapan lahar, aturan 1000 tahun per meter tidak dapat dijadikan acuan karena laju pengendapan lahar jauh lebih besar dibandingkan pengendapan hasil erosi biasa.

Untuk mengetahui umur lapisan pumice Gunung Rinjani bisa dilakukan dengan dua cara yaitu pengukuran umur relatif berdasarkan posisi relatif grafik dan pengukuran umur mutlak dengan melakukan dating radiokarbon 14.

\section{Hasil dan pembahasan}

Pengendapan material vulkanik di daerah Gangga sudah terjadi semenjak pembentukan awal Gunung Rinjani. Material yang terendapkan di daerah ini berupa material piroklastik yang merupakan hasil lemparan material gunung api serta material yang terbawa pada awan panas. Terdapat juga material hasil lahar dingin yang terbawa oleh arus sungai.

Gambar 2 menunjukkan stratigrafi perlapisan di daerah Gangga di mana terdapat 2 lapisan pumice berwarna pink yang berada di bagian atas dan lapisan pumice berwarna kuning yang berada di bagian bawah. Lapisan pumice berwarna pink diperkirakan merupakan hasil letusan besar yang terjadi di pada tahun 500 sebelum Masehi, sedangkan lapisan pumice berwarna kuning diduga merupakan hasil letusan besar yang terjadi sebelum sebelumnya. Lapisan pumice berwarna pink juga berasosiasi dengan endapan lahar yang terjadi setelah letusan tersebut. Gambar lapisan tersebut menunjukkan bahwa pumice hasil letusan pada saat itu kemudian tererosi dan terbawa ke aliran sungai dalam bentuk lahar.

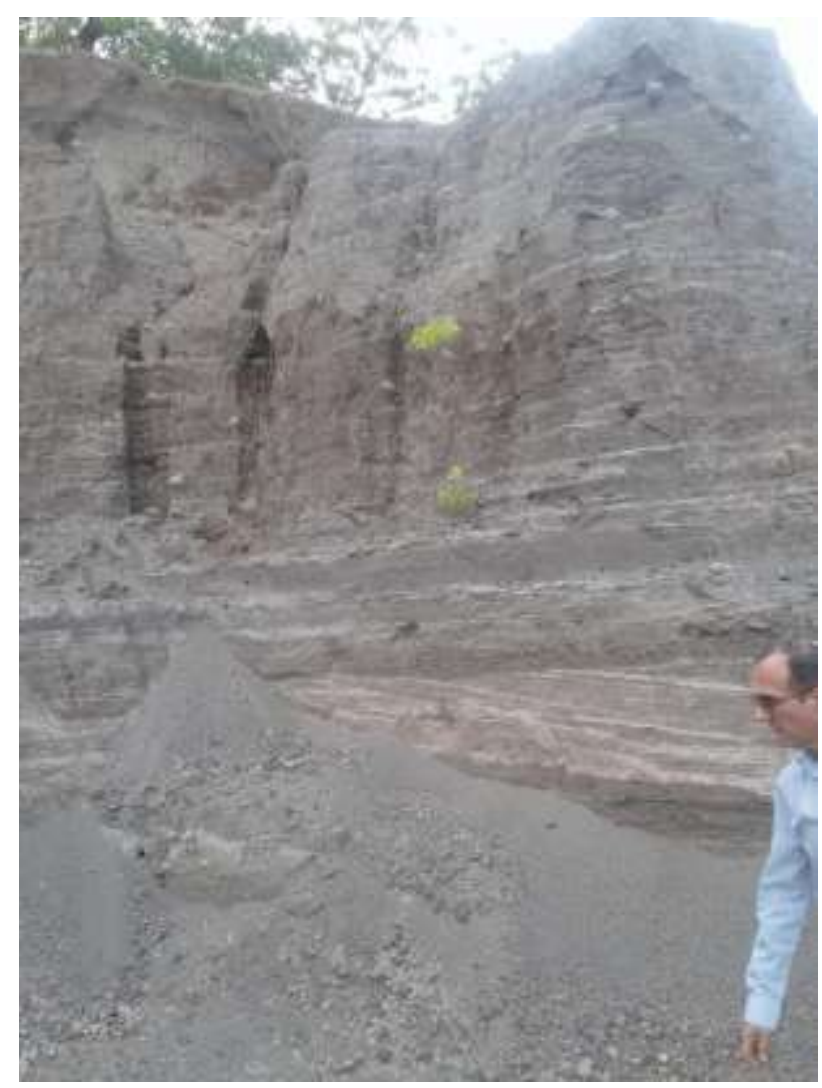

Gambar 2. Stratigrafi pelapisan di daerah Gangga

Lapisan pumice berwarna kuning berada jauh dibawah lapisan pumice yang terbawa oleh lahar. Hal inilah yang menunjukkan bahwa terdapat letusan besar di gunung Rinjani atau samalas yang yang usianya jauh lebih tua dibanding letusan tahun 500 sebelum Masehi. Temuan ini merupakan fakta baru yang belum 
pernah diungkapkan sebelumnya. Temuan ini merupakan temuan tahap awal yang harus ditindaklanjuti dengan penelitian-penelitian lanjutan dan sangat diperlukan dating radiokarbon untuk mengetahui secara lebih tapat usia letusan tersebut.

\section{Ucapan Terimakasih}

Terimakasih kami ucapkan kepada Bapak Franck Lavigne yang telah sudi berbagi ilmu selama perjalanan dari Universitas Mataram, Dinas Pertambangan, Museum hingga perjalanan menuju Gangga, Lombok Utara.

\section{Daftar Pustaka}

Billing, M. P. (1946). Structural Geology," Prentice Hall, pp. 316-318

Campbell, B.M.S. (2017). Global Climates, The 1257 Mega-Eruption of Samalas Volcano, Indonesia, and The English Food Crisis Of 1258*, Transactions of the RHS 27 (2017), pp. 87-121 (C) Royal Historical Society 2017. doi:10.1017/S0080440117000056

Lavigne, F., Degeai, J.P., Komorowskic, J.C., Guilletd, S., Roberta, V., Lahittee, P., Oppenheimerf, C., Stoffeld, M., Vidalc, C.M., Surono, Pratomo, I., Wassmera, P., Hajdask, I., Hadmoko, D.S. and Belizala, E. D. (2013). Source of the great A.D. 1257 mystery eruption unveiled, Samalas volcano, Rinjani Volcanic Complex, Indonesia, 16742-16747, PNAS, October 15, 2013, vol. 110, no. 42. www.pnas.org/lookup/suppl/doi:10. 1073 /pnas.1307520110/-/DCSupplemental.

Ludman, A. (1982). Physical Geology," Mc.Graw Hill. inc. pp.100.

Métrich, N., Vidal, C. M., Komorowski, J.C., Pratomo, I., Michel, A., Kartadinata, N., Prambada, O., Rachmat, H., Surono, (2018). New Insights into magma differentiation and storage in Holocene crustal reservoirs of the Lesser Sunda
Arc: the Rinjani-Samalas volcanic complex (Lombok, Indonesia). Downloaded from https:// academic.oup.com/petrology/advancearticleabstract/doi/10.1093/petrology/egy006/4 838192 by Carlson Library/Serials Dept. user on 12 February 2018

Syamsudin, Ashari, I., Adhi, M.A. (2018). Seismic Hazard and Microzonation Study of Tanjung Region, North Lombok (Indonesia) Using Microtremor Measurement. Jurnal Pendidikan Fisika Indonesia 14 (2) 105-110

Zuhdi M. (2019). Buku Ajar Pengantar Geologi, Duta Pustaka Ilmu, Mataram, Indonesia pp.94-110 